\title{
Gender and live weight on carcass and meat characteristics of donkeys
}

\author{
Pedro Hernández-Briano ${ }^{1,2}$ \\ Marco Antonio López-Carlos ${ }^{2}$
}

Roque Gonzalo Ramírez-Lozano
(2) Fabiola Méndez-Llorente

${ }^{1}$ Facultad de Ciencias Biológicas, Universidad Autónoma de Nuevo León, Ciudad Universitaria, San Nicolás de los Garza, N. L., México. ${ }^{2}$ Unidad Académica de Medicina Veterinaria y Zootecnia, Universidad Autónoma de Zacatecas, Gral. Enrique Estrada, Zacatecas, México. E-mail: aguileraivan@yahoo.com.mx. *Corresponding author.

\begin{abstract}
One hundred eighty-nine Catalan crossbreed donkeys (Equus africanus asinus) were used to evaluate the effect of gender (gelding, $n=106$; or female, $n=83)$ and live weight at slaughter $(L W)(<100 \mathrm{~kg}, n=25 ; 101$ to $125 \mathrm{~kg}, n=42 ; 126$ to $150 \mathrm{~kg}, n=85 ;$ and $151>\mathrm{kg}$, $n=37)$ on carcass characteristics, non-carcass components and meat and fat color. Geldings had greater $(P<0.05)$ carcass weight, carcass dressing and ${ }^{*} L$ value of subcutaneous fat than females; but females had greater $(P<0.05)$ cooling loss, $a^{*}$ value of semitendinosus muscle and $b^{*}$ value of subcutaneous fat. Donkeys with more than $126 \mathrm{~kg}$ of LW showed greater $(P<0.05)$ carcass weight and dressing and lower $(P<0.05)$ cooling loss compared to lighter donkeys. The $a^{*}$ value of semitendinosus muscle and abdominal fat was greater in heaviest donkeys ( $\left.>151 \mathrm{~kg}\right)$. Meanwhile, the $L W$ did not affect the color $\left(L^{*}, a^{*}\right.$ and $b^{*}$ values) of subcutaneous fat $(P>0.05)$. These results suggested that both gender and live weight should be considered when producing meat from donkeys. It is advisable to use geldings weighing more than $126 \mathrm{~kg}$ at slaughter to obtain the greatest weight and carcass yield.
\end{abstract}

Key words: carcass characteristics, donkey, gender, weight, meat.

Efeitos do gênero e peso ao vivo nas características de carcaça e carne de burros

RESUMO: O objetivo deste estudo foi avaliar o efeito do gênero e peso vivo (PV) nas características da carcaça, componentes não-carcaça e cor da carne e gordura dos burros (Equus africanus asinus). Foram utilizados 189 animais de sexo castrado ou feminino. Os castrados tiveram peso de carcaça maior $(P<0,05)$, molho de carcaça e uma gordura subcutânea luminosa (valor $L)$ nas fêmeas. As fêmeas apresentaram perda de resfriamento maior $(\mathrm{P}<0,05)$, "valor de cor do músculo semitendinoso e b $b^{*}$ valor de cor da gordura subcutânea. A gordura subcutânea apresentou maior $(P<0,05) b^{*}$ em animais idosos. Os burros com mais de $126 \mathrm{~kg}$ de $P V$ apresentaram maior peso de carcaça $(P<0,05)$, curativo de carcaça e menor $(P<0,05)$ perda de resfriamento em comparação com burros mais leves. O músculo semitendinoso e a gordura abdominal foram avermelhadas $(P<0,05)$, maior valor de ${ }^{*}$, em burros mais pesados $(>151 \mathrm{~kg})$. Enquanto isso, o PV não afetou a cor (valores de $L *, a * e b *)$ de gordura subcutânea $(P>0,05)$. O peso maior da carcaça e o curativo com efeitos limitados em componentes não carcaça, cor de carne e gordura foram observados em castrados com peso vivo superior a $126 \mathrm{~kg}$.

Palavras-chave: características da carcaça, burro, gênero, peso, carne.

\section{INTRODUCTION}

Donkeys (Equus africanus asinus) belong to the Equidae family, and were domesticated around 4,000BC. They are used as pack animals and saddle mounts in arid climates (AGANGA et al., 2003), but also provide milk (MONTI et al., 2006) and meat for human consumption (LORENZO et al., 2014). Global consumption of equine meat is mainly concentrated in some European countries such as Italy, France and Belgium, as part of their traditional food (STANCIU, 2015). It is difficult to estimate with precision the consumption per capita (GILL, 2005), but it was calculated in approximately $0.10 \mathrm{~kg}$ by BELAUNZARAN et al. (2015).

Consumption of equine meat is still reduced compared to other meats such as pork, chicken and beef (LOMBARDI-BOCCIA et al., 2005). However, equine meat presents desirable characteristics for consumers as they are free of growth promoters and has excellent nutritional properties (equine meat is ironrich, low fat and an important source of unsaturated 
fatty acids and omega 3 fatty acids) (LOMBARDIBOCCIA et al., 2005; TATEO et al., 2008; LORENZO et al., 2010; LORENZO et al., 2014).

Most of donkey meat comes from animals that have finished their productive life (LORENZO and CARBALLO, 2015). In this sense, AGANGA et al. (2003) described that adult African donkey provide a hot carcass yield that range from 54 to 59 $\%$. However, these yields can be considered good when compared to other species such as horses and pigs, ranging from 60 to $70 \%$ (SARRIÉS and BERIAIN, 2005; LANZA et al., 2009). Horses have a carcass composition of $70 \%$ muscle, $20 \%$ bone and $10 \%$ fat; and therefore, produce more lean meat than other species. Different studies in horses reported that factors such as breed, gender and age affect the weight and carcass yield and the meat quality (JUÁREZ et al., 2009; FRANCO et al., 2011). To date there are a few scientific reports about factors affecting yield and meat characteristics of donkeys. Thus, the aim of this study was to evaluate the effect of gender and live weight on carcass characteristics, non-carcass components, and color of muscle and fat of donkeys.

\section{MATERIALS AND METHODS}

The study was carried out at the meat packing plant "Empacadora de Carnes Fresnillo S.A. de C.V.”, Federal Inspection Type plant E42, located in the State of Zacatecas, Mexico. One hundred and eighty-nine Catalan crossbreed donkeys were slaughtered from April to June, 2014. Animals were classified according to their gender (geldingor female). Live weight (LW) was measured immediately before sacrifice using an electronic scale (model PG, Torrey, México). According to LW, animals were classified in four groups: group one with $<100 \mathrm{~kg}$, group two from 101 to $125 \mathrm{~kg}$, group three from 126 to $150 \mathrm{~kg}$ and group four from $>151 \mathrm{~kg}$.

Donkeys were slaughtered in accordance to the Official Mexican Standard of methods for slaughter domestic and wild animals (NOM-033-SAG/ ZOO-2014). After slaughter, hot carcass weight was registered and the head, legs and skin were removed and weighed individually using an electronic scale (EQB 100/200, Torrey, Mexico). Gastrointestinal content was weighed and subtracted to $\mathrm{LW}$ to obtain the empty BW. Carcasses were chilled for $24 \mathrm{~h}$ at $2{ }^{\circ} \mathrm{C}$ and $98 \%$ of relative humidity, and then were weighed to obtain the cold carcass weight. Hot carcass dressing ([hot carcass weight/empty BW] $\times 100)$, cold carcass dressing ([cold carcass weight/empty BW] $\times 100)$, and cooling loss (hot carcass weight - cold carcass weight/ hot carcass weight) were calculated.

Non-carcass components (head, skin, stomach, small intestine, large intestine and cecum, heart, lungs, liver and spleen) were weighed from each animal separately using an electronic scale (EQB $100 / 200$, Torrey, México) and yields of these organs were calculated as percentage of empty BW. The $\mathrm{pH}$ was measured in the longissimus thoracis muscle at $45 \mathrm{~min}$ post-mortem using a $\mathrm{pH}$ meter equipped with a penetration electrode and thermometer (Hanna Instruments, HI-9025, Woonsocket, RI). The color $\left(\mathrm{L}^{*}, \mathrm{a}^{*}, \mathrm{~b}^{*}\right)$ of subcutaneous fat and semitendinosus muscle was measured directly on the carcass at $45 \mathrm{~min}$ post-mortem using a portable spectrophotometer (CR-400, Konica Minolta Sensing Inc., Japan). The semitendinosus muscle was used to obtain meat color determination by the impossibility of dissect carcasses during the production process of the packing plant.

Data were analyzed as a completely randomized design, including the fixed effects of gender and LW of donkeys. Analysis of variance was performed using the PROC GLM procedure of SAS version University Edition (SAS Inst. Inc., Cary, NC). When significant effects were observed, a comparison of means was performed using the Tukey method with the LSMEANS instruction. Differences were considered significant at $\mathrm{P}<0.05$.

\section{RESULTS}

Geldings had greater $(\mathrm{P}<0.05)$ carcass weight, carcass dressing and $\mathrm{L}^{*}$ value of subcutaneous fat color than females (Table 1). Females had greater $(\mathrm{P}<0.05)$ carcass cooling loss, small intestine weight (as percentage of the empty $\mathrm{BW}$ ), $\mathrm{a}^{*}$ value of semitendinosus muscle color and $\mathrm{b}^{*}$ value of subcutaneous fat color. However, the $\mathrm{pH}$ value, most non-carcass components or other color values $\left(\mathrm{a}^{*}, \mathrm{~b}^{*}\right.$ or $\left.\mathrm{L}^{*}\right)$ in meat or fat were not affected $(\mathrm{P}>0.05)$ by gender.

Donkeys with more than $126 \mathrm{~kg}$ of $\mathrm{LW}$ showed greater $(\mathrm{P}<0.05)$ carcass weight and hot carcass dressing and lower $(\mathrm{P}<0.05)$ cooling loss compared to lighter donkeys (Table 2 ), but the cold carcass dressing was greater $(\mathrm{P}<0.05)$ in donkeys of more than $101 \mathrm{~kg}$. However, the $\mathrm{pH}$ of the longissimus muscle $(\mathrm{P}>0.05)$ was unaffected by LW. In addition, the head, the skin and the large intestine (as percentage of empty $\mathrm{BW})$ were greater $(\mathrm{P}<0.05)$ in the lighter $(<100 \mathrm{~kg})$ donkeys. Also, the hearth and the liver occupied a greater percentage of the empty BW $(\mathrm{P}<0.05)$ in donkeys with a LW lower than $125 \mathrm{~kg}$, 
Table 1 - Least square means for carcass characteristics, non-carcass components ${ }^{1}$ and color $\left(\mathrm{L}^{*}\right.$, $\mathrm{a}^{*}$ and $\mathrm{b}^{*}$ values) ${ }^{2}$ of the semitendinosus muscle, subcutaneous and abdominal fat in donkeys according to their gender.

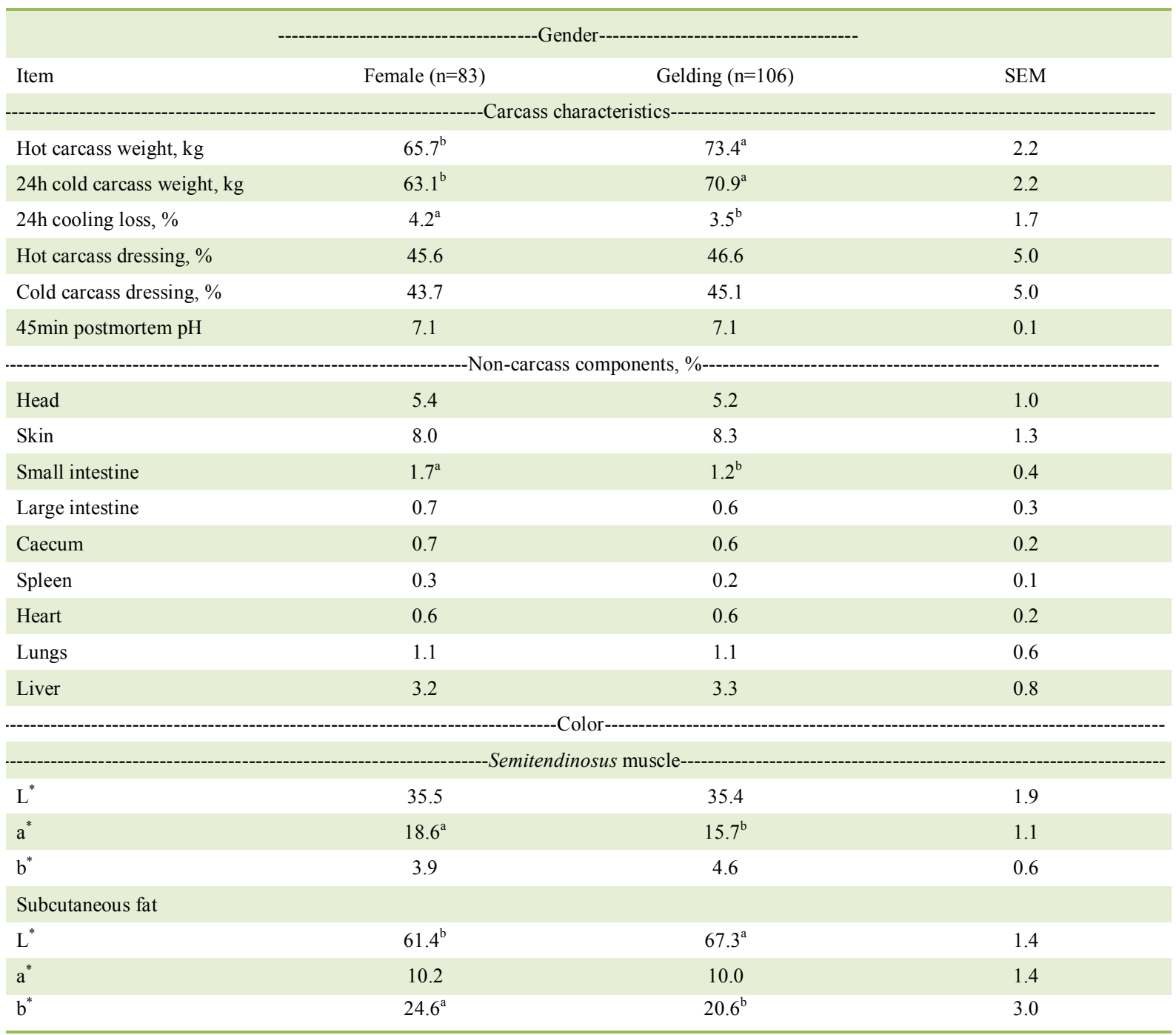

${ }^{\mathrm{ab}}$ Different superscript letters in a row are different $(\mathrm{P}<0.05) .{ }^{1}$ Non-carcass components are expressed as percentage of empty body-weight. ${ }^{2}$ Color scale: $\mathrm{L}^{*}=$ lightness $\left(0=\right.$ black, $100=$ white); $\mathrm{a}^{*}=$ red to green (positive values = red, negative values $=$ green); $\mathrm{b}^{*}=$ yellow to blue (positive values $=$ yellow, negative values $=$ blue) .

while the lungs were smaller $(\mathrm{P}<0.05)$ in the group of heaviest donkeys $(>151 \mathrm{~kg})$.

The semitendinosus muscle showed greater $(\mathrm{P}<0.05) \mathrm{a}^{*}$ value (redness) in the heaviest donkeys $(>151 \mathrm{~kg})$; however, the $\mathrm{L}^{*}$ and $\mathrm{b}^{*}$ values were similar $(\mathrm{P}>0.05)$ independently of the LW. The color of abdominal fat was darker $\left(\mathrm{L}^{*}\right.$ value) and reddish $\left(\mathrm{a}^{*}\right.$ value) $(\mathrm{P}<0.05)$ in donkeys over $150 \mathrm{~kg}$, but the $\mathrm{b}^{*}$ value was unaffected $(\mathrm{P}>0.05)$ by $\mathrm{LW}$ of donkeys. Meanwhile, the LW did not affect the color $\left(\mathrm{L}^{*}, \mathrm{a}^{*}\right.$ and $b^{*}$ values) of subcutaneous fat $(\mathrm{P}>0.05)$.

\section{DISCUSSION}

AGANGA et al. (2003) reported that African donkeys had greater hot carcass dressing (59\%) and cold carcass dressing (51\%) than those observed in this study (lower than 50\%). Earlier data by POLIDORI et al. (2008) reported hot and cold carcass yields of $54 \%$ and $53 \%$ respectively for Martina Franca donkeys, which were greater than those observed in the present study. Moreover, SARRIÉS and BERIAIN (2006), FRANCO et al. 
Table 2 - Least square means for carcass characteristics, non-carcass components ${ }^{1}$ and color $\left(\mathrm{L}^{*}, \mathrm{a}^{*}\right.$ and $\mathrm{b}^{*}$ values) ${ }^{2}$ of the semitendinosus muscle, subcutaneous and abdominal fat in donkeys according to their live weight at slaughter.

\begin{tabular}{|c|c|c|c|c|c|}
\hline Item & $<100(\mathrm{n}=25)$ & $101-125(n=42)$ & $126-150(n=85)$ & $>151(\mathrm{n}=37)$ & SEM \\
\hline Hot carcass weight, $\mathrm{kg}$ & $47.2^{\mathrm{c}}$ & $65.9^{\mathrm{b}}$ & $74.3^{\mathrm{a}}$ & $75.1^{\mathrm{a}}$ & 2.4 \\
\hline $24 \mathrm{~h}$ cold carcass weight, $\mathrm{kg}$ & $45.0^{\mathrm{c}}$ & $62.8^{\mathrm{b}}$ & $71.9^{\mathrm{a}}$ & $72.2^{\mathrm{a}}$ & 2.2 \\
\hline $24 \mathrm{~h}$ cooling loss, $\%$ & $2.1^{\mathrm{a}}$ & $2.2^{\text {ba }}$ & $1.6^{\mathrm{c}}$ & $1.4^{\mathrm{c}}$ & 0.1 \\
\hline Hot carcass dressing, $\%$ & $44.1^{b}$ & $45.4^{\mathrm{b}}$ & $47.9^{\mathrm{a}}$ & $49.3^{\mathrm{a}}$ & 1.0 \\
\hline Cold carcass dressing, $\%$ & $42.0^{\mathrm{b}}$ & $45.2^{\mathrm{a}}$ & $44.3^{\mathrm{a}}$ & $45.4^{\mathrm{a}}$ & 1.0 \\
\hline $45 \mathrm{~min}$ postmortem $\mathrm{pH}$ & 6.9 & 7.1 & 7.3 & 6.9 & 0.1 \\
\hline Head & $6.0^{\mathrm{a}}$ & $5.0^{\mathrm{b}}$ & $4.3^{\mathrm{b}}$ & $4.5^{b}$ & 0.2 \\
\hline Skin & $8.8^{\mathrm{a}}$ & $7.9^{\text {ba }}$ & $7.1^{\mathrm{b}}$ & $6.8^{\mathrm{b}}$ & 0.3 \\
\hline Small intestine & 1.7 & 1.5 & 1.4 & 1.1 & 0.2 \\
\hline Large intestine & $0.9^{\mathrm{a}}$ & $0.6^{\mathrm{b}}$ & $0.5^{\mathrm{b}}$ & $0.5^{\mathrm{b}}$ & 0.06 \\
\hline Caecum & 0.7 & 0.7 & 0.6 & 0.5 & 0.1 \\
\hline Spleen & 0.3 & 0.2 & 0.2 & 0.1 & 0.04 \\
\hline Heart & $0.7^{\mathrm{a}}$ & $0.7^{\mathrm{a}}$ & $0.5^{\text {ba }}$ & $0.4^{\mathrm{b}}$ & 0.1 \\
\hline Lungs & $1.5^{\mathrm{a}}$ & $1.4^{\mathrm{a}}$ & $1.1^{\mathrm{a}}$ & $0.7^{\mathrm{b}}$ & 0.2 \\
\hline Liver & $1.8^{\mathrm{a}}$ & $1.6^{\mathrm{a}}$ & $1.3^{\mathrm{b}}$ & $0.9^{c}$ & 0.1 \\
\hline $\mathrm{L}^{*}$ & 36.5 & 37.8 & 36.8 & 30.7 & 2.6 \\
\hline$a^{*}$ & $17.8^{b}$ & $16.8^{\mathrm{b}}$ & $14.7^{b}$ & $19.3^{\mathrm{a}}$ & 1.6 \\
\hline$b^{*}$ & 3.8 & 4.9 & 3.8 & 4.5 & 1.0 \\
\hline $\mathrm{L}^{*}$ & 64.0 & 65.1 & 61.5 & 66.8 & 2.0 \\
\hline$a^{*}$ & 9.7 & 7.9 & 10.1 & 12.6 & 2.0 \\
\hline$b^{*}$ & 19.4 & 21.2 & 20.5 & 20.3 & 4.0 \\
\hline
\end{tabular}

${ }^{\mathrm{abc}}$ Different superscript letters in a row are different $(\mathrm{P}<0.05) .{ }^{1}$ Non-carcass components are expressed as percentage of empty BW. ${ }^{2} \mathrm{Color}$ scale: $\mathrm{L}^{*}=$ lightness $(0=$ black, $100=$ white $) ; \mathrm{a}^{*}=$ red to green $($ positive values $=$ red, negative values $=$ green $) ; \mathrm{b}^{*}=$ yellow to blue $($ positive values $=$ yellow, negative values $=$ blue $)$.

(2011) and NIVIA et al. (2014) stated a range from 50 to $70 \%$ for hot carcass dressing of horses. It can be expected that carcass yields of horses will be greater because there are specialized breeds in meat production unlike donkeys.

In this study, carcasses obtained showed higher values of cooling loss when compared to the values of other farm animal species reported in the literature. MAMANI-LINARES and GALLO (2011) reported values for cooling loss of $1.37 \%$ in Llamas and $2.50 \%$ in horses. Similarly, FURTADO et al.
(2010) observed cooling loss ranging from 2 to $2.5 \%$ in equine meat, which are lower than those observed in the present study.

Despite it has been documented that castration reduces carcass yields (LAZZORONI et al., 2008; JUÁREZ et al., 2009), in this study the carcasses of geldings were heavier $(\mathrm{P}<0.05)$ than females. NIVIA et al. (2014) reported greater averages for hot carcass weight and hot carcass dressing in males. In this study, there were no significant interactions, coinciding with FURTADO et al. (2010) 
who reported that there was no interaction between sex and size for hot carcass yield of horses.

Meanwhile, SARRIÉS and BERIAIN (2006) observed that there was no effect of gender on hot carcass weight. Similarly, NIVIA et al. (2014) argued that gender has a low effect on these variables, and in agreement with previously reported by MARTIN-ROSSET and DULPHY (1987) who mentioned that gender differences do not affect the relative growth of heavy horses.

Previous research indicated that the effect of gender on the hot carcass weight and dressing is more related to the amount of fat than to the amount of muscle (HORCADA et al., 1998; DÍAZ et al., 2003). Meanwhile, FURTADO et al. (2010) reported a hot carcass dressing below $51 \%$ in Mestizo horses, without differences due to weight, age and gender. In this study, females had greater cooling loss than males. These results can be explained by the presence of a greater subcutaneous fat appreciated in males, which protect carcass against dehydration during cooling (VERGARA and MOLINA, 1998; FRANCO et al., 2011).

AGANGA et al. (2003) mentioned that the yields of this species may be affected by the state of maturity, physical condition or degree completed, they also mentioned that the carcass yield of donkeys decreased with age, arguing that as the donkeys get older, increased their weight, perhaps because the fat percentage increased, thereby decreasing the ratio of muscle:bone. In horses, FURTADO et al. (2010) reported an interaction between sex and age, in which males over 8 years were those with the largest hot carcass dressing. However, SALGUEIRO et al. (2008) mentioned that fattening period of the animals is more important than age to determine carcass dressing. The carcass dressing obtained in this study agree with those reported by POLIDORI et al. (2008), who observed an increase of $4 \%$ in donkeys of $120 \mathrm{~kg}$ compared with those of $100 \mathrm{~kg}$.

The information available on weight and yield of the non-carcass components in donkeys is limited. However, SANTOS-RICALDE et al. (2011) there have been reported differences in the weight of the viscera between pigs slaughtered at different weights which agrees with what was observed in the present study, where the yield of viscera was affected by the weight of the donkeys. PÉREZ-MELÉNDEZ et al. (2007) reported that live weight at slaughter has an effect on the weight of body components such as head, skin, heart, liver, kidneys, lungs and legs; but, the same authors reported that gender did not influence the weight of the non-carcass components, according with what was observed in the present study. Despite the same authors reported greater weight in organs of castrated males, probably this was due to a greater proportion of fat.

The meat color is an important characteristic for the consumer that is influenced by factors such as genetics, sex, age at slaughter and nutrition (PRIOLO et al., 2002; RIPOLL et al., 2012). POLLIDORI et al. (2016) mentioned that the luminosity and red coloration of the meat is due to the muscle myoglobin content and is influenced by feeding and production system. In addition, several investigations mention a relation between the color pattern with the intramuscular fat content and water in meat (LORENZO et al. 2017). However, an inverse relationship was observed between fat and water content in meat (SMITH et al., 2011).

The difference of fat content between males and the females evaluated in this work could explain the differences observed in meat color; as well as between the lighter donkeys and the heavier ones, because higher intramuscular fat content has been reported in older and heavier donkeys (DOMÍNGUEZ, et al., 2015, POLIDORI et al., 2015; DE PALO et al., 2017).

\section{CONCLUSION}

In summary, both gender and live weight are important factors that affects carcass and meat characteristics of donkeys. Geldings provide carcasses of greater weight and paler subcutaneous fat, which have less cooling loss than females. Donkeys with live weight at slaughter $>126 \mathrm{~kg}$, have greater carcass weights and dressing, and lower cooling loss than lighter donkeys. In addition, the non-carcass components are reduced when live weight increases.

\section{ACKNOWLEDGEMENTS}

The authors express their gratitude to the owners and personnel of the meat packing plant "Empacadora de Carnes Fresnillo S.A. de C.V.", Federal Inspection Type plant E42, for their supportand assistance to carrying out this study.

\section{DECLARATION OF CONFLICTING INTERESTS}

The authors declared no potential conflicts of interest with respect to the research, authorship, and/or publication of this article.

\section{REFERENCES}

AGANGA, A. A., et al. Carcass analysis and meat composition of the donkey. Pakistan Journal of Nutrition, v. 2, n. 3, p. 138-147, 2003. Available from: <http://citeseerx.ist.psu.edu/ 
viewdoc/download?doi=10.1.1.533.1513\&rep=rep1\&type=pdf $>$. Accessed: Jun. 22, 2017.

BELAUNZARAN, X., et al. Horse-meat for human consumption -current research and future opportunities. Meat Science, $v$. 108, p. 74-81, 2015. Available from: <https://doi.org/10.1016/j. meatsci.2015.05.006>. Accessed: May 20, 2017. doi: 10.1016/j. meatsci.2015.05.006

DE PALO, P., et al. Martina Franca donkey meat quality: influence of slaughter age and suckling technique. Meat Science. v. 134 p. 128-134, 2017. Available from: <https://doi.org/10.1016/j. meatsci.2017.07.025>. Accessed: Nov. 20, 2017. doi: 10.1016/j. meatsci.2017.07.025

DÍAZ, M. T., et al. Physico-chemical characteristics of carcass and meat Manchego-breed suckling lams slaughtered at different weights. Meat Science, v. 65, p. 1085-1093, 2003. Available from: $<$ https://doi.org/10.1016/S0309-1740(03)00032-9>. Accessed: Jun. 20, 2017. doi: 10.1016/S0309-1740(03)00032-9.

DOMÍNGUEZ, R., et al. Effect of slaughter age on foal carcass traits and meat quality. Animal, v. 9, p. 1713-1720, 2015. Available from: <https://doi.org/10.1017/S1751731115000671>. Accessed: Jul. 15, 2017. doi: 10.1017/S1751731115000671.

FRANCO, D., et al. Carcass quality of Galician Mountain foals. Centro Tecnológico de la Carne. San Cibrao das Viñas. Archivos de Zootecnia, v. 60, n. 231, p. 385-388, 2011. Available from: <http:// dx.doi.org/10.4321/S0004-05922011000300017>. Accessed: May 15, 2017. doi: $10.4321 / \mathrm{S} 0004-05922011000300017$.

FURTADO, C. E., et al. Influência do peso vivo, da idade e do sexo sobre características de carcaças de equinos. Revista Brasileira de Zootecnia. v. 39, n. 12, p. 2683-2686, 2011. Avaiable from: <http:// dx.doi.org/10.1590/S1516-35982010001200018>. Accessed: Jul. 15, 2017. doi 10.1590/S1516-35982010001200018.

GILL, C.O. Safety and storage stability of horse meat for human consumption. Meat Science, v. 71, n. 4, p. 506-513, 2005. Available from: $<$ https://doi.org/10.1016/j.meatsci.2005.04.030>. Accessed: May 15, 2017. doi: 10.1016/j.meatsci.2005.04.030.

HORCADA, A., et al. Effect of sex on meat quality of Spanish lamb breeds (Lancha and Rasa Aragonesa). Journal of Animal Science, v. 67 , p. $541-547,1998$. Available from: $<$ https://doi. org/10.1017/S1357729800032975 > . Accessed: May 17, 2017. doi: $10.1017 / \mathrm{S} 1357729800032975$.

JUÁREZ, M., et al. Breed effect on carcass and meat quality of foals slaughtered at 24 months of age. Meat Science, v.83, p. 224-228, 2009. Available from: <https://doi.org/10.1016/j. meatsci.2009.04.022>. Accessed: May 17, 2017. doi: 10.1016/j. meatsci.2009.04.022

LANZA, M., et al. Meat quality and intramuscular fatty acid composition of Sanfratellano and Haflinger foals. Meat Science, $v$. 81, p. 142-147, 2009. Available from: <https://doi.org/10.1016/j. meatsci.2009.04.022>. Accessed: Jun. 17, 2017. doi: 10.1016/j. meatsci.2009.04.022.

LAZZARONI, C., BIAGINI, D. Effect of pre-and post-pubertal castration on Piemontese male cattle. II: Carcass measures and meat yield. Meat Science. v.80, p. 442-448, 2008. Available from: $<$ https://doi.org/10.1016/j.meatsci.2008.01.007>. Accessed: Jun. 17, 2017. doi: 10.1016/j.meatsci.2008.01.007.
LOMBARDI-BOCCIA, et al. Aspects of meat quality: trace elements and B vitamins in raw and cooked meats. Journal Food and Composition Analysis, v. 18, p 39-46, 2005. Available from: $<$ https://doi.org/10.1016/j.jfca.2003.10.007>. Accessed: Jun. 20, 2017. doi: $10.1016 /$ j.jfca.2003.10.007.

LORENZO, J. M., et al. Intramuscular fatty acid composition of "Galician Mountain" foals breed: Effect of sex, slaughtered age and livestock production system. Meat Science, v. 86, p. 825-831, 2010. Available from: <https://doi.org/10.1016/j. jfca.2003.10.007>. Accessed: Jun. 18, 2017. doi: 10.1016/j. jfca.2003.10.007.

LORENZO, J. M., et al. Carcass characteristics, meat quality and nutritional value of horsemeat: A review. Meat Science, v. 96, p. 1478-1488, 2014. Available from: <https://doi.org/10.1016/j. meatsci.2013.12.006>. Accessed: Jun. 18, 2017. doi: 10.1016/j. meatsci.2013.12.006.

LORENZO, J. M., CARBALLO, J. Changes in physic-chemical properties and volatile compounds throughout the manufacturing process of dry-cured foal loin. Meat Science, v. 99, p. 44-51, 2015. Available from: <https://doi.org/10.1016/j.meatsci.2014.08.013>. Accessed: Jun. 18, 2017. doi: 10.1016/j.meatsci.2014.08.013.

LORENZO, J.M., et al. Technological aspects of horse meat products- A review. Food Research International, v. 102, p. 176-183, 2017. Available from: <https://doi.org/10.1016/j. foodres.2017.09.094>. Accessed: May 18, 2017. doi: 10.1016/j. foodres.2017.09.094.

MAMANI-LINARES, L. W.; GALLO, C. Chemical composition and instrumental quality of bovine, llama (lama glama) and horse meat under an extensive production system. Revista de Investigaciones Veterinarias del Perú, v. 22, n. 4, p. 301311, 2011. Available from: <http://www.scielo.org.pe/scielo. php?pid $=$ S1609-91172011000400003\&script $=$ sci_arttext $>$. Accessed: May 18, 2017.

MARTIN-ROSSET, W.; DULPHY, J. P. Digestibility interactions between forages and concentrates in horses: influence of feeding level - comparison with sheep. Livestock Production Science, v. 17, p. 263-276, 1987. Available from: <https://doi. org/10.1016/0301-6226(87)90071-6>. Accessed: May 20, 2017. doi: 10.1016/0301-6226(87)90071-6.

MONTI, G., et al. Efficacy of donkey's milk in treating highly problematic cow's milk allergic children: An in vivo and in vitro study. Pediatric Allergy Immunology, v. 18, p. 258-264, 2006. Available from: <https://doi.org/10.1111/j.1399-3038.2007.00655. $\mathrm{x}>$. Accessed: May 20,2017. doi:10.1111/j.1399-3038.2007.00655.x.

NIVIA, O. A., et al. Determination of the slaughter volume and evaluation of quantitative variables of horses sacrificed in a slaughterhouse. Zootecnia Tropical, v. 32, n. 1, p. 83-89, 2014. Available from: <http://www.scielo.org.ve/scielo.php?pid=S079872692014000100009\&script=sci_arttext $>$. Accessed: May 10, 2017.

NOM-033-SAG/ZOO-2014. Slaughter methods for domestic and wild animals. Available from: <http://201.140.167.80/wp-content/ uploads/2016/08/NOM-033-SAG-ZOO-2014.pdf>. Accessed: May 17, 2017.

PÉREZ-MELÉNDEZ, P., et al. Effect of Slaughter Weight and Sex on the Carcass of Suffolk Down x German Merino Precocious Suckling Lambs. Revista Científica, FCV-LUZ, v.17, n.6, p. 
621-626, 2007. Available from: <http://www.scielo.org.ve/scielo. php? script $=$ sci_arttext\&pid $=\mathrm{S} 0798-22592007000600010>$. Accessed: Jun. 20, 2017.

POLIDORI, P., et al. A comparison of the carcass and meat quality of Martina Franca donkey foals aged or 12 months. Meat Science, v.106, p. 6-10, 2015. Available from: <https://doi.org/10.1016/j. meatsci.2015.03.018>. Accessed: May 20, 2017. doi: 10.1016/j. meatsci.2015.03.018.

POLIDORI, P., et al. Quality of donkey meat and carcass characteristics. Meat Science, v. 80, p. 1222-1224, 2008. Available from: <https://doi.org/10.1016/j.meatsci.2008.05.027>. Accessed: May 20, 2017. doi: 10.1016/j.meatsci.2008.05.027.

PRIOLO, A., et al. Effect of grass or concentrate feeding system on lamb carcass and meat quality. Meat Science, v.62, p. 179185, 2002. Available from: <https://doi.org/10.1016/S03091740(01)00244-3>. Accessed: Jul. 19, 2017. doi: 10.1016/S03091740(01)00244-3.

RIPOLL, G., et al. Influence of alfalfa grazing-based feeding systems on carcass fat color and meat quality of light lambs. Meat Science, v. 90 , p. $457-464,2012$. Available from: $<$ https://doi. org/10.1016/j.meatsci.2011.09.007>. Accessed: Jul. 20, 2017. doi: 10.1016/j.meatsci.2011.09.007.

SALGUEIRO, J., et al. Efecto del peso de sacrifico y la raza en la canal de terneros alimentados con ensilados. Archivos de zootecnia, v. 57, n. 219, p. 295-306, 2008. Available from: <https:// dialnet.unirioja.es/servlet/articulo? codigo $=3027750>$. Accessed: Sept. 18, 2017.

SANTOS-RICALDE, et al. Carcass yield and thoracic and abdominal viscera growth from 25 to $45 \mathrm{~kg}$ in creole hairless Pigs. Revista Científica, FCV-LUZ, v. 21, n. 5, p.396 - 402, 2011.
Available from: $\quad<$ http://200.74.222.178/index.php/cientifica/ article/view/15663/15637>. Accessed: Sept. 18, 2017.

SARRIÉS, M. V.; BERIAIN, M. J. Carcass characteristics and meat quality of male and female foals. Meat Science, v. 70,p. 141-152, 2005 . Available from: <https://doi.org/10.1016/j.meatsci.2004.12.006>. Accessed: Sept. 18, 2017. doi: 10.1016/j.meatsci.2004.12.006.

SARRIÉS, M. V.; BERIAIN, M.J. Color and texture characteristics in meat of male and female foals. Meat Science, v. 74, p. 738-745, 2006. Available from: <https://doi.org/10.1016/j. meatsci.2006.06.005>. Accessed: Sept. 18, 2017. doi: 10.1016/j. meatsci.2006.06.005.

STANCIU, S. Horse meat consumption - between scandal and reality. Procedia Economics and finance, v. 23, p. 697-703, 2015. Available from: $<$ https://doi.org/10.1016/S2212-5671(15)00392-5>. Accessed: Sept. 18, 2017. doi: 10.1016/S2212-5671(15)00392-5.

SMITH, A. M., et al. Proximate composition and energy content of beef steaks as influenced by USDA quality grade and degree of doneness. Meat Science, v. 89, p. 228-232, 2011. Available from: $<$ https://doi.org/10.1016/j.meatsci.2011.04.027>. Accessed: May 20, 2017. doi: 10.1016/j.meatsci.2011.04.027.

TATEO, A., et al. Physicochemical properties of meat of Italian Heavy Draft horses slaughtered at the age of eleven months. Journal of Animal Science, v.86, n. 5, p. 1205-2014, 2008. Available from: <https://doi.org/10.2527/jas.2007-0629>. Accessed: May 20, 2017. doi: 10.2527/jas.2007-0629.

VERGARA, H.; MOLINA, A. Influence of sex and slaughterweight on carcass and meat quality in light and mediumweight lambs produced in intensive systems. Meat Science, v. 52,p. 221-226, 1998. Available from: <https://doi.org/10.1016/S0309-1740(98)00171-5>. Accessed: May 21, 2017. doi: 10.1016/S0309-1740(98)00171-5. 